\title{
Mitotic Activity in Cowpea (Vigna unguiculata (L.) Land Race “Olaudi” Walp) in Nigeria
}

\author{
Peggy Obaseojei Willie, Peter Osobase Aikpokpodion \\ Department of Genetics and Biotechnology, Faculty of Science, University of Calabar, \\ Calabar, Nigeria \\ Email: peggyarikpootu@yahoo.com
}

Received 22 November 2014; accepted 17 May 2015; published 20 May 2015

Copyright (C) 2015 by authors and Scientific Research Publishing Inc.

This work is licensed under the Creative Commons Attribution International License (CC BY).

http://creativecommons.org/licenses/by/4.0/

(c) () Open Access

\section{Abstract}

Cowpea, Vigna unguiculata is a major staple for millions of households in the tropics. A cowpea land race, "Olaudi" collected from South-Eastern Nigeria was investigated for mitotic indices during cell division. Root tips were pre-treated with 8-hydroxyquinoline for three hours, fixed in Carnoy's solution (alcohol-acetic acid solution 3:1 v/v) for 24 hours, hydrolysed in $1 \mathrm{NHCl}$ and squashed in aceto-orcein. Various stages of mitosis were recorded to determine mitotic activity in dividing cells. Results obtained showed that active cell division occurred between 7.00 AM and 2.00 PM but peaks between 11.00 AM and 1.00 PM. Although cells at the prophase stage were in a continuum, they became observable between 8.00 AM and 3.00 PM, but greater proportion of cells was observed at 12.00 PM. Cells at metaphase were generally observed during a six hours period between 8.00 AM and 1.00 PM, but the peak period was 11.00 AM. Mitotic activity at anaphase commenced around 10.00 AM late morning but plateaus for two hours early afternoon between 12.00 PM and 2.00 PM. Telophase activity was mostly observed at $11.00 \mathrm{AM}$ within a five hour period between 9.00 AM and 2.00 PM. Mitotic index peaked at $1.00 \mathrm{PM}$ with $65.3 \%$ of cells in active cell division, with a concomitant high mean germination percentage $(63.5 \%)$. This study provides useful basic information to guide further cytogenetics research in the genetic improvement of this local cowpea landrace.

\section{Keywords}

Mitotic Index, Mitosis, Cowpea, Germination Percentage

\section{Introduction}

Vigna unguiculata (L.) Walp (cowpea) is one of the most important food grain legumes of the family Fabaceae 
found in the tropics and sub-tropics between $35^{\circ} \mathrm{N}$ and $30^{\circ} \mathrm{S}$ across Asia, Africa, South America and Southern Europe [1] [2]. The center of diversity of wild cowpea (where you find the most variation) is in southern and southeastern Africa; the center of diversity of cultivated cowpea is in West Africa [3]. Today, the most primitive form of the plants is being distributed to other parts of the world and is now a broadly adapted and highly variable crop cultivated around the world. It is highly domesticated in West Africa [4]. In Nigeria, the vernacular names of some of the cowpea land race include "Olaudi”, "Akidi”, "Ileje” and "Ileje-Ajaka" [5].

Cowpea is a drought-tolerant, warm-weathered crop that is well adapted in the dry savannah and it grows well in poor soils of sandy composition of $85 \%$ and less than $0.2 \%$ organic matter and low levels of phosphorus [6]. Cowpea is used as a multipurpose legume providing foliage leaf, green pods and grains. Cowpea is considered nutritious with a protein content of about $24.3 \%$, carbohydrate content of about $63.64 \%$, fat content of about $1.9 \%$, fiber content of about $6.3 \%$ and water $8 \%-9 \%$ [1] [7]. Cowpea seed coat contains flavonoid, an antioxidant found in fruits and vegetables which protect human cells from damage caused by radicals [8]. It improves soil fertility by fixing atmospheric nitrogen for soil enrichment [9]. The plant is shade-tolerant and therefore compatible as an intercrop with maize, millet, sorghum sugarcane and cotton. Cowpea is consumed as food especially its grain, green pod and fresh foliage green leaves. It is used as a cover crop as it has the ability to spread and provide ground cover, thus suppressing weeds and giving some protection against erosion. These attributes Coupled with its quick growth and rapid ground cover among other uses and importance have made the plant an essential component of sustainable subsistence agriculture especially in dry regions with little rainfall and poor acidic soil [10]. Its diversity of uses, nutritive contents and storage qualities has made the plant an integral part of the farming system in the West African region [9].

Plant growth and development results from a combination of three processes at the cellular level: cell division (mitosis), cell expansion and cell differentiation [11]. Although cowpea is a multipurpose legume of high nutritional value, there is little or no information on the cytogenetics of its landraces. The continuous supply of new germplasm material as donor of various genes of agronomic importance is an important prerequisite for further improvement of cowpea cultivars especially as there are concerns that the yield peaks in major crops species including cowpea have been reached. Landraces of cowpea can undoubtedly contribute towards the development of germplasm pools. Cell division or mitosis and cell expansion determines cell number and cell size in a mature organ hence its yield [11]. Cytogenetic studies require knowledge of the most appropriate time for root tip collection for adequate observation of the chromosomes. This could best be determined through mitotic index studies. The mitotic index of a cell population has long been regarded as an important criterion for the growth and multiplication of the cells and tissues. One of the reasons for the mitotic indexing of species is to generate data which is important for breeding purposes [12] [13]. It becomes important therefore to study the mitotic index of the cow pea landrace, "Olaudi”.

\section{Materials and Methods}

Cowpea land race, "Olaudi” used in this study was obtained from Dr. Udensi Ugorji's germplasm collection. Seeds were grown in petri dishes to obtain roots and the germination percentage was calculated and recorded. Root tips of "Olaudi" were collected at every hour, from 6 AM to 6 PM. Immediately after harvesting, the root tips were pre-treated with 8-hydroxyquinoline and kept at room temperature for three hours. The pre-treated root tips were rinsed in distilled water and fixed in a cold mixture of ethanol and acetic acid (3:1). Fixed samples were used after 12 - $24 \mathrm{~h}$ or transferred to $70 \%$ alcohol and stored in refrigerator until required. The fixed materials were hydrolysed in $1 \mathrm{NHCl}$ at $60^{\circ} \mathrm{C}$ for $5-8 \mathrm{~min}$. Meristematic portions werecut off unto clean slides in a drop of aceto-orcein stain. The meristem was gently tapped with a squashing rod. A cover slip was placed over the top and the excess stain was removed with filter paper by applying a firm thumb pressure. The slides were sealed with nail hardener [7] [14]. Prepared slides were viewed under the microscope at a magnification of $\times 100$. Photographs of dividing cells were taken using a Canon Power Shot A630, 8.0 mega pixel digital camera with $4 \times$ optical zoom. Mitotic index for each root collection time was calculated from the number of dividing cells and the total number of cells using the formula:

$$
\frac{\text { Number of dividing cells } \times 100}{\text { Total number of cells }}
$$

A complete Randomised Design was used in this study and data were collected based on the mitotic index at every hour from 6 AM to 6 PM. Data were subjected to Analysis of Variance (ANOVA) test. Significant means 
obtained were separated using Least Significant Difference (LSD) test. The germination percentage of was calculated using the formula

$$
\frac{\text { Number of germinated seeds } \times 100}{\text { Total number of seeds }}
$$

\section{Results and Discussion}

The results obtained showed that the germination percentage of cowpea (“Olaudi”) was $63.5 \%$ and mitotic divisions occurred at all intervals of the day, from 6 AM - 6 PM. From the hours of 9 AM and 1 PM, mitotic division increased rapidly and reduced significantly from 2 PM - 6 PM. Chromosome counts gave a diploid chromosome number of $2 \mathrm{n}=22$ (Figure 1 )

The peak period of cell division was between 11 AM and 2 PM (Figure 2). The peak period for cells at prophase stage was observed at $12 \mathrm{PM}$, while that at metaphase stage was 11 AM. The peak period for cells at anaphase and telophase stage was observed at $2 \mathrm{PM}$ and 11 AM respectively. Cell division occurred at all times during the day (Figure 2). The percentage of dividing cells was higher between 11 AM to 2 PM. At 6 AM, dividing cells started to increase with high percentage of prophase cells. The percentage of cells at prophase remained relatively high till about 2 PM when the percentage started decreasing. Metaphase cells increased after prophase and continued mostly between 7 AM to 12.00 noon. The number of cells at anaphase started to increase at about $11 \mathrm{AM}$ and continued till about $2 \mathrm{PM}$.

Analysis of variance (Table 1 ) showed significant effect of time of harvest on mitotic index of "Olaudi" at P < 0.01. Root tips harvested at $1 \mathrm{PM}$ had the highest mitotic index of $65.3 \%$ while those harvested at $6 \mathrm{PM}$ had the least mitotic index of $12 \%$. Root tips harvested at 1 PM and 2 PM revealed cells with a significantly higher mitotic index than the cells of root tips harvested at 3 PM to 6 PM as shown in Table 2. Also, the mitotic index at 6 AM - 7 AM, was significantly different from the mitotic index at 9 AM - 11 AM, but there was no difference in the mitotic index of cells between 11 AM and 12 PM of root tip harvest.

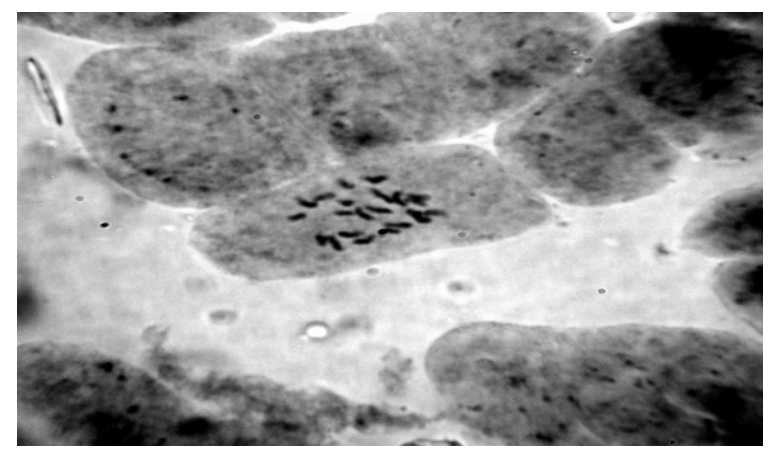

(a)

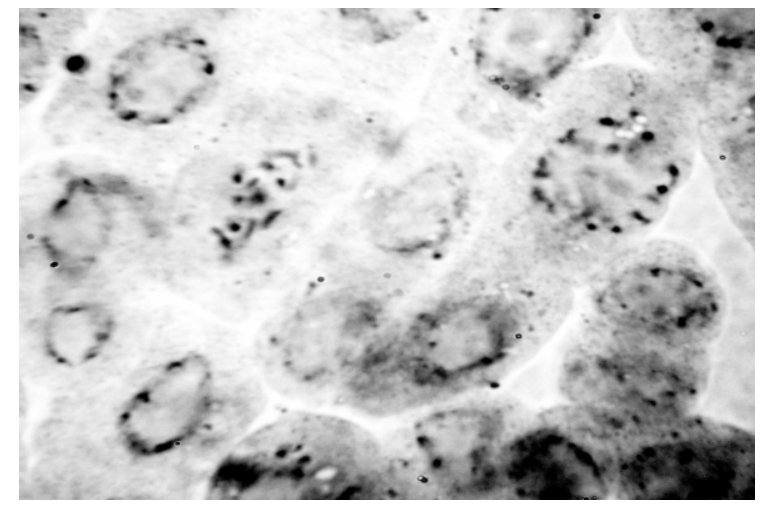

(c)

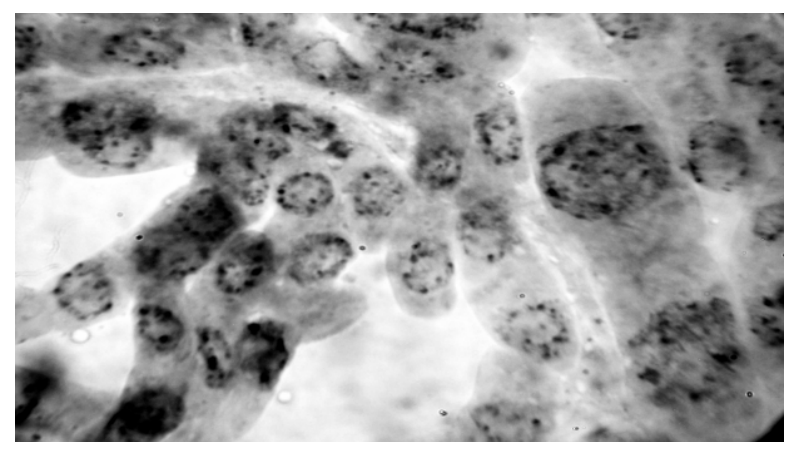

(b)

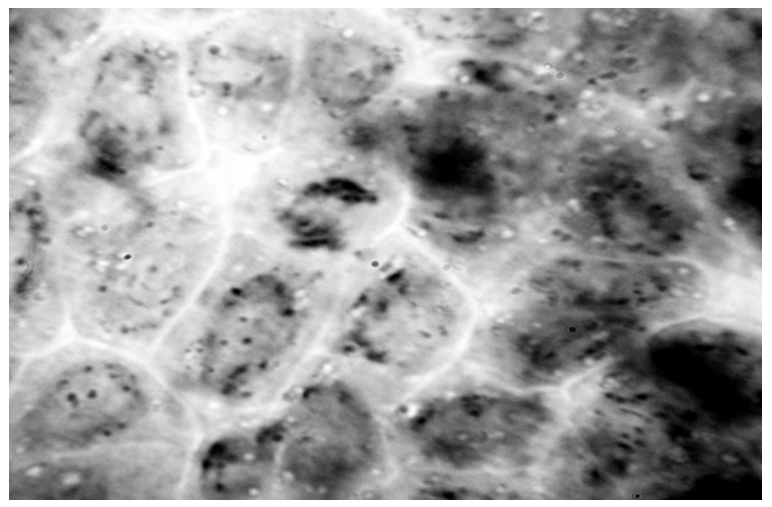

(d)

Figure 1. (a) Metaphase chromosomes of "Olaudi” (2n = 22); (b) Chromosomes of "Olaudi” at 11 Am; (c) Chromosomes of “Olaudi” at 12 pm; (d) Chromosomes of "Olaudi” at 2 pm. (a) ×4000 mag; (b) ×2000 mag; (c) ×2000 mag; (d) ×2000 mag. 


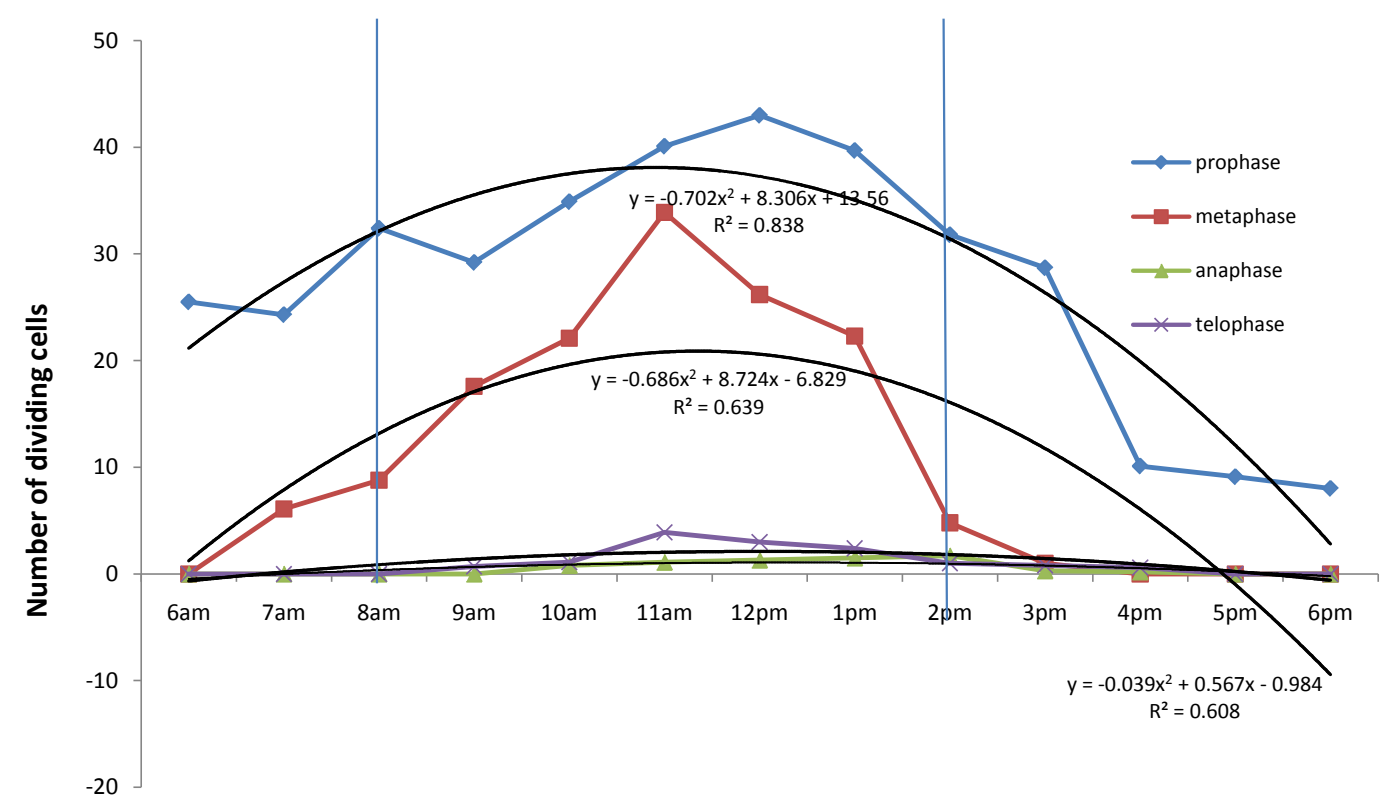

Time of mitotic cell counts

Figure 2. Line graph and trendline showing proportion of cells at various stages of division during a 12-hour period of the day.

Table 1. Analysis of variance showing mean square of effects of harvest time on mitotic index of “Olaudi”.

\begin{tabular}{cccc}
\hline Source of variation & DF & MS & F \\
\hline Time of harvest & 12 & 1144.30 & $2.49^{* *}$ \\
Error & 26 & 64.78 & \\
Total & 38 & & \\
\end{tabular}

${ }^{*},{ }^{* *}$ indicate significance at $\mathrm{P}<0.05$ and $\mathrm{P}<0.01$ respectively.

Table 2. Data for mitotic indices at various times of harvest.

\begin{tabular}{|c|c|c|c|c|c|c|c|c|c|c|c|c|c|c|}
\hline Time & $6 \mathrm{AM}$ & $7 \mathrm{AM}$ & $8 \mathrm{AM}$ & $9 \mathrm{AM}$ & $10 \mathrm{AM}$ & $11 \mathrm{AM}$ & 12 noon & $1 \mathrm{PM}$ & $2 \mathrm{pPM}$ & 3 PM & $4 \mathrm{PM}$ & 5 PM & $6 \mathrm{PM}$ & LSD \\
\hline
\end{tabular}

Crop improvement is very important in the sustainability and security of food especially in Nigeria. This can be achieved by exploiting the potentials of landraces as sources of novel disease and abiotic stress resistant genes or combination of genes. Cell division is a continuous process and can be quantified by using the mitotic index. Mitotic index is mainly carried out to examine the proliferation status of cells and to determine if the plant is an actively dividing one. It is also used to quantify differences in cell division when an environmental parameter is changed [12] [13]. Cell division in "Olaudi" increased rapidly during the day which may be due to cellular metabolism and photosynthesis [15]. A diploid chromosome number $2 \mathrm{n}=22$ obtained in this study agrees with earlier results in cowpea as reported by [16]. The level of prophase stage was dominant at all the time intervals and it increased during the early hours of the day but reduced during the late hours. The processes of metaphase and anaphase, no doubt requires most energy, therefore, the observation of the highest number of metaphase and anaphase cells at $11 \mathrm{AM}$ and 2 PM respectively corresponds to the period when most plants record a high photosynthetic level due to maximum availability of sunlight and thus, a high rate of synthesis of energy in the form of ATP [17]. Similar results have been reported in African yam bean [15] and in edible cocoyams [18].

The proliferation status of a cell determines its germination rate hence the high germination percentage recorded in the plant. This is in line with the conclusions of [8] that cell division leads to increase in mitotic index as well as germination, growth and development of the plant which is based on several factors including oxygen 
concentration, light and moisture etc. In comparison, mitotic index in African Yam Bean peaked at $12 \mathrm{PM}$ and 2 PM [15], Treculia africana peaked at 4 PM [19] while cowpea peaked at 1 PM. This, according to [18], implies that the peak of photosynthesis as well as mitosis may vary between species and can be exploited taxonomically. The information presented in this work is expected to serve as a first step for further cytogenetic research, exploitation and improvement of this crop.

\section{Acknowledgements}

Authors wish to acknowledge Dr. U. Udensi for providing some seeds of "Olaudi" landrace and the research support by Ms. Patience Ekong of the Department of Genetics and Biotechnology, University of Calabar.

\section{References}

[1] Purseglove, J.W. (1988) Tropical Crops: Dicotyledons. Longman Group, London.

[2] Gogile, A., Andargie, M. and Muthuswamy, M. (2013) Screening Selected Genotypes of Cowpea [Vigna unguiculata (L.) Walp.] for Salt Tolerance during Seedling Growth Stage. Pakistan Journal of Biological Sciences, 16, 671-679.

[3] Padulosi, S. (1993) Genetic Diversity, Taxonomy, and Ecogeographic Survey of the Wild Relatives of Cowpea (V. unguiculata). PhD Thesis, University of Louvain La Neuve, Belgium.

[4] Duke, J.A. (1981) Vigna unguiculata (L.) Walp. Species unguiculata: Handbook of Legumes of World Economic Importance. Plenum Press, New York. http://dx.doi.org/10.1007/978-1-4684-8151-8

[5] Udensi, O., Edu, E.A., Ikpeme, E.V., Ebiwgai, J.K. and Ekpe, D.E. (2012) Biometrical Evaluation and Yield Performance Assessment of Cowpea (Vigna unguiculata (L.) Walp) Landraces Grown under Lowland Tropical Conditions. International Journal of Plant Breeding and Genetics, 6, 47-53. http://dx.doi.org/10.3923/ijpbg.2012.47.53

[6] Wanatabe, I., Hakoyama, S., Terao, T. and Singh, B.B. (1997) Evaluation Methods for Drought Tolerance of Cowpea. In: Singh, B.B., Mohan-Raj, D.R., Dashiell, K.E. and Jackai, L.E., Eds., Advances in Cowpea Research, Co-Publication of International Institute of Agriculture (IITA) and Japan Institute for Agricultural Sciences (JIRCAS) IITA, Ibadan, 141-146.

[7] Singh, R.J. (1993) The Handling of Plant Chromosomes. Plants Cytogenetics, 4, 7-24.

[8] Isabelle, D., Leon-Kloosterzie, K.M. and Koomneel, M. (2000) Influence of the Testa on Seed Dormancy, Germination and Longetivity in Arabidopsis. Plant Physiology, 122, 403-413. http://dx.doi.org/10.1104/pp.122.2.403

[9] Eaglesham, A.R., Ayanaba, J.A., Rama V.R. and Eskew D.L. (1992) Mineral N Effects on Cowpea and Soybean Crops in Nigeria Soil: Amounts of Nitrogen Fixed and Accrual to the Soil. Plant and Soil, 68, 183-186. http://dx.doi.org/10.1007/BF02373704

[10] Fatokun, C.A., Tarawali, S.A., Singh, B.B., Kormawa, P.M. and Tamò, M. (2002) Challenges and Opportunities for Enhancing Sustainable Cowpea Production. Euphytica, 91, 181-187.

[11] Wang, L. and Ruan, Y.L. (2013) Regulation of Cell Division and Expansion by Sugar and Auxin Signalling. Frontiers in Plant Science, 4,163.

[12] Darbelley, N.D., Driss-Ecole, D. and Perbal, G. (1989) Elongation of Mitotic Activity of Lentil Roots Grown in Microgravity. Plant Physiological Biochemistry, 27, 341-347.

[13] Driss-Ecole, D., Schoevaert, D.D., Noin, M. and Perbal, G. (1994) Densitomeric Analysis of Nuclear DNA Content in Lentil Roots Grown in Space. The Cell, 81, 59-64.

[14] Okoli, B.E. (1992) Field, Herbarium and Laboratory Techniques. Mbeyi and Associates (Nig.) Ltd., Port Harcourt, 239 p.

[15] Adesoye, A.I. and Nnadi, N.C. (2011) Mitotic Chromosomes Studies of Some Accessions of African Yam Bean, Sphenostylis sternocarpa (Hochst. ex. A. Rich.) Harm. African Journal of Plant Science, 5, 835-841. http://dx.doi.org/10.5897/AJPS10.199

[16] Bennet, M.D., Smith, J.B. and Heslop-Harrison, J.S. (1982) Nuclear Amount in Angiosperm. Proceedings of the Research Society of London, 216, 179-199. http://dx.doi.org/10.1098/rspb.1982.0069

[17] Klug, W.S., Cummings, M.R. and Spencer, C.A. (2006) Concepts of Genetics. 8th Edition, Pearson Education International, Upper Saddle River, NJ. ISBN 0131918338, 676 p.

[18] Ekanem, A.M. and Osuji, J.O. (2006) Mitotic Index Studies on Edible Cocoyams (Xanthosoma and Colocasia spp.). African Journal of Biotechnology, 5, 846-849

[19] Osuji, J.O. and Owei, S.D. (2010) Mitotic Index Studies on Treculia africana Decne. Austria Journal Agricultural Engineering, 1, 25-28. 